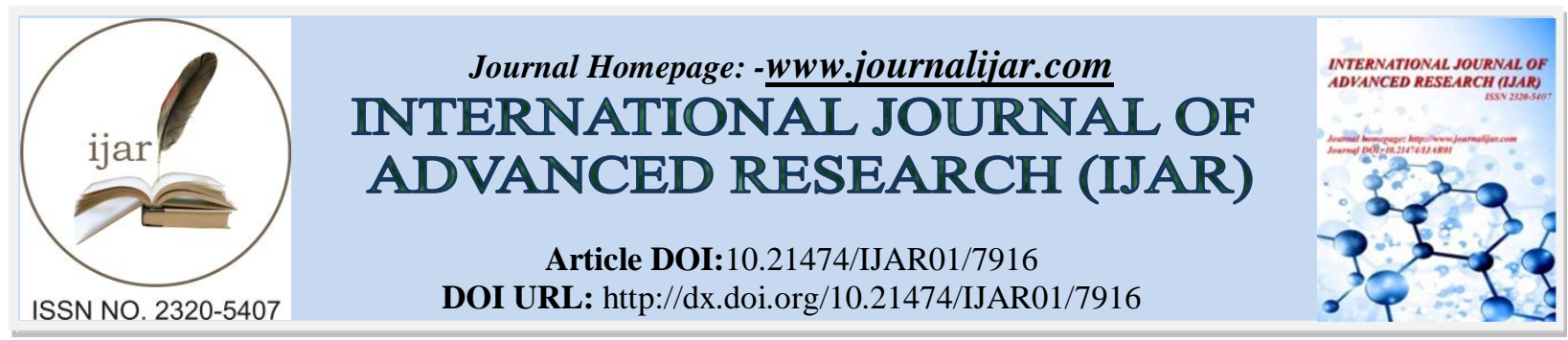

RESEARCH ARTICLE

\title{
MOLECULAR SYSTEMATIC STUDY OF TWO SOLANACEOUS GENERA DATURA L. AND BRUGMANSIA PERS. BASED ON ITS SEQUENCES OF NRDNA.
}

\author{
Dhanya C. ${ }^{1}$, Shabir A. Rather ${ }^{2}$ and Devipriya $\mathbf{V}^{3}$. \\ 1. Research \& PG Department of Botany, SN College, Kollam, Kerala, South India, \\ 2. Department of Botany, Delhi University, New Delhi, India, \\ 3. Department of Botany, SN College, Chempazhanthy, Kerala, South India.
}

\section{Manuscript Info}

Manuscript History

Received: 13 August 2018

Final Accepted: 15 September 2018

Published: October 2018

\begin{abstract}
Phylogenetic analysis was performed based on ITS 1 and 2 sequences to determine monophyly of Datura and Brugmansia and to understand their relationships. The results support the splitting of Datura and Brugmansia into two distinct genera (BS 100 \& 91). D. ceratocaula earlier considered as the connecting link between the two genera, is nested within the Datura clade (BS 57) as a distinct species. Although the three conventional sections of Datura viz. Dutra, Ceratocaulis \& Datura (Stramonium) stand well supported (BS 100, $100 \& 83$ ), D. kymatocarpa, D. leichhardtii and D. pruinosa appear shifted from Section Dutra to Section Datura, corroborating earlier observations. D. discolor remains nested within the Section Dutra, refuting earlier suggestions as intermediary or ancestral role. But the divergence of $D$. discolor from the remaining taxa within the section Dutra as a clearly supported subclade (BS 100) may be suggestive of the subdivision of Section Dutra into two subsections. This subdivision of section Dutra however remains to be appraised using cladistical studies incorporating both molecular and morphological data. The infrageneric grouping of Brugmansia into cold and warm groups viz. sections Sphaecarpium and Brugmansia exclusively on the basis of fruit shape and habitat lacks adequate support in the present analysis. But fruit shape appears not consistent as the warm climatic inhabitant $B$. aurea with trumpet shaped flowers sports egg-shaped fruits. Hence we propose subdivision of the genus into two sections on the basis of the more stable corolline form, and the proposition is well supported by molecular data viz. section Brugmansia (with trumpet and/or funnel shaped flowers, with fruits fusiform or egg-shaped) and section Sanguinea (with tubular flowers and consistently egg-shaped or short oval fruits).
\end{abstract}

Copy Right, IJAR, 2018,. All rights reserved

\section{Introduction:-}

The Solanaceae forms a monophyletic group comprising approximately 105 genera and 2030 species, and includes many important crop plants such as tomatoes, potatoes, egg-plants, chilli peppers etc (APG III, 2009). The family is traditionally classified into two subfamilies, Cestroideae with straight or bent embryos and capsular fruits, and 
Solanoideae characterized by curved embryos and berry-like fruits (D'Arcy, 1979, 1991; Hunziker, 1979, 2001; Olmstead and Palmer 1992). Recently 8 clades have been recognized within the family (APG III, 2009), among which Clade Solanoideae includes two important genera Datura L. and Brugmansia Pers. Both genera are rich in alkaloids which have been utilized in traditional as well as modern medicines.

Datura, a genus of drug plants with several weedy species, comprises of 12 species distributed in the Tropical and Temperate regions of the world, of which three have been reported from South India (Sasidharan, 2004; The Plant List, 2013; Nandini et al. 2015). The members are glabrous or minutely pubescent shrub-like herbs, with large entire and sinuate or deeply-toothed leaves, large solitary white or purple flowers and armed and globose capsules. Brugmansia native to South America, includes 12 taxa of small ornamental trees, of which only two have so far been reported from South India (Sasidharan, 2004; Randhava and Mukhopadhyay, 1986; The Plant List, 2013). The members are profusely flowering with large attractive pendulous flowers and unarmed spindle shaped capsules.

Brugmansia and Datura are morphologically similar with hairy leaves that exude a stinking smell when crumpled or injured, and perfumed funnel-shaped flowers. Datura differs from Brugmansia in having annual or biennial habit with erect flowers and rounded spiny capsules. On the other hand, Brugmansia is perennial with pendulous flowers and elongated smooth fruits.

The species diversity of Datura is centred on Mexico and southwestern United States in North America (Hammer et al 1983; Mace et al 1999; Jiao et al 2002). The three species of Datura (D. inoxia, D. metel and D. ferox) that occur in South America are believed to have been introduced there in pre-Columbian times (Hunziker 1979; Nee 1991). Its occurrence in Australia and India are recent and human-mediated (Symon and Haegi, 1991). However, the Old World origin of Datura metel from the Indian Subcontinent has been advocated by Indian researchers on the basis of Indian lexical evidence, Arabic and Indic texts, and Southern Indian iconographic representations (Siklos, 1993; Geetha and Gharaibeh, 2007). The genus Brugmansia includes woody species, several of which are considered to be hybrids, unknown in the wild state.

The plants belonging to Brugmansia and Datura contain tropane alkaloids, mainly atropine and scopolamine. Several members are hallucinogenic used by indigenous people in the new world (Schultes, 1979; Dabur et al. 2004). Some are sources for the commercial production of hyoscine, an alkaloid of medicinal interest as a spasmolytic, anaesthetic and anti-motion sickness drug. Datura has been used to treat skin ulcers, arthritis, rheumatism, hemorrhoids, asthma, lung infections, etc. Brugmansia is widely cultivated as ornamentals, because of their attractive large tubular flowers. Bristol $(1966,1969)$ reported that species of Brugmansia are used for medicinal and psychotropic preparation by the Sibundoy Indians.

Brugmansia is closely related to the genus Datura in both its morphology and chemistry, and was earlier considered to be synonymous with Datura. Persoon (1805) collated all arboreal perennial varieties into a separate genus Brugmansia. Bernhardi (1833) opined that the differences recorded by Persoon are not sufficient for separating out the taxon into a separate genus, and included Brugmansia as a section within the genus Datura. Lagerheim (1895) elevated Brugmansia to the status of an independent genus. This uncertainty remained for a long time until Lockwood (1973) transferred all woody members of Datura in a separate genus, Brugmansia.

Majority of the morphological characters are conserved in both, and differences between the two are mainly confined to the habit and fruit characters (Fig. 1). Datura ceratocaula which is restricted to Mexico and Central America, is a semi-aquatic hollow-stemmed prostrate creeping plant. It is considered as the connecting link between herbaceous Datura and shrubby Brugmansia due to its unique combination of characters (Bernhardi, 1833; Safford, 1921; Griffin and Lin, 2000). The plant is a herbaceous annual with erect flowers, circumscissile calyx, tetralocular ovary and carunculate seeds like Datura, but has smooth, pendulous, fleshy fruits characteristic of Brugmansia.

Although the chloroplast gene rbcL has been utilized for solving plant phylogenetic controversies at higher taxonomic levels (Chase et al. 1993; Qui et al. 1998), the nrDNA ITS region is being increasingly depended upon to resolve inter-generic and inter-specific phylogenetic concerns (Baldwin, 1992; Kron and King, 1996). This region is fast-evolving and serves as a method of direct DNA sequence analysis for detecting reticulate phenomena which would be appropriate for subgeneric or subspecific cladistic studies (Gaut et al. 2000). 
Bye and Sosa (2013) studied the molecular phylogeny of the genus Datura using matK, ndhF, trnH-psbA, trnL-F and morphological markers, and supported the previous recognition of Brugmansia as sister of Datura in the subtribe Datureae by Olmstead et al, 2008. The analyses also supported the recognition of Datura as monophyletic with the monospecific section Ceratocaulis as the sister to the remaining species of Datura. Mace et al. (1999) performed cluster analysis of AFLP data for seven species of Datura and six species of Brugmansia and considered the genera as sister groups. However both these studies have focused largely on the distinct generic status of Brugmansia and the subgeneric classification within the genus Datura. The present study while addressing the systematic and phylogenetic relationships between the members of the two genera Datura and Brugmansia using ITS markers, focuses more on the infrageneric interrelationships between the members of Brugmansia.

\section{Materials and Methods:-}

Taxon sampling:-

Five taxa of Brugmansia and four taxa of Datura from Kerala and Tamil Nadu, India, are included in the present study. Author citations are given in Tables 1. The voucher specimens of the taxa collected have been deposited in SNCH herbarium.

DNA extraction, amplification, and sequencing:Genomic DNA was extracted using a DNeasy Plant Mini Kit (Qiagen, Amsterdam, The Netherlands). DNA amplification and sequencing of the ITS region were performed using the primers ITS1 and ITS2 (White et al. 1990).

The polymerase chain reaction (PCR) was performed with standard methods using AccuPower HF PCR premix (Bioneer, Daejeon, Korea) in $20 \mu \mathrm{l}$ volumes containing $2 \mu \mathrm{l}$ of $10 \mathrm{X}$ buffer, $300 \mu \mathrm{M}$ dNTPs and 1 unit of HF DNA polymerase. To this $1 \mu \mathrm{l}$ of a $10 \mathrm{pM}$ solution of each primer, $1 \mu \mathrm{l}$ of genomic DNA and distilled water added to make a total volume of $20 \mu \mathrm{l}$. PCR amplification was performed with 40 cycles (Denaturation for $1 \mathrm{~min}$ at $94^{\circ} \mathrm{C}$, annealing for $1 \mathrm{~min}$ at $49^{\circ} \mathrm{C}$, and $1 \mathrm{~min}$ of extension at $72^{\circ} \mathrm{C}$ followed by a last cycle of final extension for $5 \mathrm{~min}$ at $72^{\circ} \mathrm{C}$ ). PCR products were checked for the presence of appropriate bands on a $0.8 \%$ agarose gel, purified, and sequenced at SciGenome, Kochi. Sequences comprised of ITS1, 5.8S, and ITS2 regions. Forward and reverse sequences were edited and assembled using the computer program DNA Baser (vers. 3) (2011). All sequences have been deposited in GenBank (Table 2).

\section{Phylogenetic analyses:-}

A total of 45 nucleotide sequences (including all outgroups) were aligned using Clustal $\mathrm{X}$ vers. 2.0.11 (Thompson et al. 1997) followed by manual adjustments in Clustal W (Thompson et al.1994). All positions containing gaps and missing data were eliminated. Phylogenetic analyses were done using neighbour-joining (NJ) methods and RAxML (maximum likelihood, ML). ML analyses were done using RAxML-HPC BlackBox 8.0.9 (Stamatakis 2006; Stamatakis et al. 2008). The best-fit model was determined using jModel Test vers. 0.1.1 ascuel 2003) by the Akaike Information Criterion (AIC) and the maximum likelihood method; the lowest AIC score and highest log-likelihood score. Relative support for the clades recovered was assessed via bootstrap analyses using 1,000 replicates in both analyses. The following criteria were used to assess bootstrap support percentages (BP): 50-70 \%, low; 71-84 \%, moderate; $85-100 \%$, strong. The results of MP and NJ analyses are congruent with those from Bayesian analyses.

\section{Results:-}

Sequence analyses: -

45 accessions of 21 species were used for the analysis and out of 21 species 9 were generated new, 9 sequences consists of five Brugmansia and four Datura species. All the sequences have been deposited in GenBank (Tables 2).

\footnotetext{
Alignment:-

The ITS alignment comprises of total of 45 accessions of 21 species and has an aligned length of 636 base pairs. The ITS sequences used for analysis were having $362(56.9 \%)$ identical sites and remaining variable and informative sites - Major variations were observed in ITS1 and ITS2, while the 5.8s region remained conserved. Mean pairwise percentage is $89.6 \%$. Of the total sites, $3.1 \%$ consists of gap.

\section{Maximum Likelihood analyses:-}

Monophyly of both the genera (Datura and Brugmansia) is proved and is well supported (BS 100 and 91). Datura ceratocaula once considered to be a hybrid or connecting link between Datura and Brugmansia is very well placed in
} 
Datura clade (BS 57) and is grouped along with other species. The genus Brugmansia appears to be split into two with B. sanguinea and B. vulcanicola diverging out as a distinct cluster (BS 91).

\section{Discussion:-}

The results obtained from the present study support the separation of Brugmansia from Datura by earlier taxonomists, and the tree topology obtained using ITS data is also congruent to their study (Text Fig. 2). In the light of the present observations, the systematic inter-relationships between and within the two genera are discussed below.

\section{Elevation of Brugmansia as a new genus:-}

Earlier taxonomic studies based on morphological as well as phytochemical data consider Brugmansia to be synonymous with Datura (Bernhardi, 1833; Bristol 1966), the grouping being challenged by several others who advocated its elevation as an independent genus (Persoon, 1805; Lagerheim 1895). The erection of Brugmansia as a separate genus by Lockwood (1973) was generally accepted, yet doubted by some taxonomists despite it being recognized under the International Code of Botanical Nomenclature (Nee, 1991). The protein chemotaxonomy study based on amino acid sequences of ferredoxin supported the conventional classification that included Brugmansia within the genus Datura (Mino 1994, 1995). Phylogenetic study using ITS1 sequences, isozymes and morphology on 12 species of Datura and Brugmansia by Mace et al. (1999) separated the arborescent species of Brugmansia as a genus from the herbaceous species of Datura. Pollen morphological studies on Datura and Brugmansia also separated these two taxa (Persson et al.1999). Dhanya et al. (2016) proposed two pollen types for the two genera namely Datura-type and Brugmansia-type. Later floristic studies also recognized the distinctiveness of the two genera (D'Arcy 1973; Haegi 1976; Shaw 2000; Hunziker 2001). The present study also revealed two major clades - Datura clade (BS 100) characterised morphologically by herbs, erect flowers and spiny capsules and Brugmansia clade (BS 91) encompassing mostly small trees having pendant flowers and smooth capsules (Text Fig. 1). The split of Datura and Brugmansia is well supported (BS 80).

\section{The taxonomic status of Datura ceratocaula:-}

Datura ceratocaula has been considered to be a hybrid of Datura and Brugmansia, owing to its unique combination of traits being a herbaceous annual with erect flowers, circumscissile calyx, tetralocular ovary and carunculate seeds like Datura and bearing smooth, pendulous, fleshy berries similar to Brugmansia. The fruits however dehisce irregularly like some species of Datura. This reticulation of characters from the two major genera in D. ceratocaula was raised as a major argument in support of the inclusion of Brugmansia as a section under the genus Datura. Consequently, D. ceratocaula was considered as the connecting link between the two genera (Bernhardi, 1833; Safford, 1921). However, later molecular studies revealed that the species is well nested within the genus Datura (Mace et al. 1999; Luna-Cavazos et al.2000; Jiao et al. 2002; Bye and Sosa, 2013). The present molecular data also suggests that D. ceratocaula is a distinct species, nested within the Datura clade (BS 57), amply separated from the Brugmansia clade.

The taxonomy based on fruit morphological characters recognizes three sections in the genus Datura (excluding section Brugmansia in some earlier classifications) viz. Dutra, Ceratocaulis and Datura (Bernhardi 1833; Dunal 1852; Safford 1921; Hammer et al. 1983). Sections Dutra and Datura are characterized by dry dehiscent spiny capsules, pendant in the former and erect in the latter. On the contrary, section Ceratocaulis exhibits spineless pendant fleshy berries that disintegrate irregularly (Knapp, 2002). Avery et al. (1959) found D. ceratocaula to be incompatible with all other species of the genus, and hence included it singly under the section Ceratocaulis of the genus Datura. The distinctiveness of section Ceratocaulis is well-supported in the present study also (BS 57).

\section{Subgeneric classification of Datura:-}

Datura has been traditionally subdivided into three sections viz. Section Datura comprising annual herbs with erect spiny septifragal capsules (Datura stramonium, D. quercifolia and D. ferox), Section Ceratocaulis with pendant unarmed foraminicidal capsules including only one species - D. ceratocaula and Section Dutra or Stramonium encompassing perennial herbs with pendant spiny septifragal or foraminicidal capsules. The latter is the largest and includes 6-8 species - D. discolor, D. inoxia, D. kymatocarpa, D. lanosa, D. metel, D.pruinosa, D. reburra, D. wrightii and D. leichhardtii (Safford, 1921; Avery et al. 1959; Fosberg, 1959; Hammer et al. 1983).

The largest Section Dutra is heterogenous and shows a mixture of characters of the former two sections. Consequently, several researchers have proposed its division into either independent sections or subsections. 
Division of genus Datura into four sections was proposed by erecting a fourth section either by separating out D. discolor alone as Section Discolor (Mace et al. 1999) or by subdividing Section Dutra into two (Jiao et al. 2002). Luna-Cavazos et al. (2009) also recognized two distinct clades within section Dutra from their cladistic analysis of morphological characters. Bye and Sosa (2013) shifted D. kymatocarpa, D. leichhardtii and D. discolor from conventional Section Dutra to Section Datura and opined that no new section needs to be added, retaining the three conventional sections proposed by Bernhardi (1833).

The three conventional sections of Datura stand well supported in the phylogenetic tree from the current study also (BS 100, 100 and 83). D. kymatocarpa, D. leichhardtii and D. pruinosa from Section Dutra appear shifted to Section Datura, corroborating the observations by Bye and Sosa (2013). The only difference is seen with regard to D. discolour, which remained stationed within the Section Dutra and yet diverged from the remaining members of the section, forming a clearly defined subclade (BS 100). The nodding, septifragal capsules of D. discolor led Barclay (1959) to consider the species as an intermediate between the sections Dutra and Stramonium (Datura). This was supported by Mace et al. (1999 and 2000) from isozyme and ITS-1 analyses, who considered that D. discolor might be a recombinant from taxa of both sections or it may represent the ancestral form of the two groups. However in the present study, D. discolor was well-nested within the Section Dutra, and the molecular data do not support its intermediary or ancestral ranking. The divergence of the species from the remaining taxa within the section Dutra observed in the phylogenetic tree (Fig.2) is not sufficient enough for the erection of a new section as was proposed earlier (Mace et al. 1999). All the same it forms a clearly supported subclade (BS 100) which may be suggestive of the subdivision of Section Dutra into two subsections and this remains to be appraised using cladistical studies incorporating both molecular and morphological data.

\section{Subgeneric classification of Brugmansia:-}

Hay et al (2012) divided the genus Brugmansia into two sections - Section Brugmansia - the warm group with long, spindle shaped fruits and Section Sphaerocarpium - the cold group with short, egg-shaped fruits. They observed that hybridization is not possible across the sectional limits. The former includes B. aurea, B. x candida, B. insignis, B. suaveolens and B. versicolor, while the latter includes B. arborea, B. x rubella, B. sanguinea and B. vulcanicola. This classification based mainly on habitat and fruit shape, ignores coralline features. But the short, egg shaped fruit of B. arborea makes it a misfit in Section Brugmansia characterized by long spindle shaped fruits. Hence fruit shape alone cannot be depended upon as a distinguishing character for subdividing the genus into sections.

Haegi (1976) observed that in Brugmansia large trumpet or funnel shaped corollas are characterized by flared throats and limbs, while they were scarcely flared out in tubular corollas. Morphological observations reveal a close association between tubular corollas and short egg shaped fruits, while large flared out corollas are not linked to any particular fruit form. So when the two traits are considered together, the members of the genus diversify into two clear morphologically distinct groups - (1) a larger group including taxa having large trumpet or funnel shaped and flared out corollas along with long spindle shaped or short egg shaped fruits and (2) a second group with narrow tubular corollas and short egg shaped fruits.

The phylogenetic tree observed in our study shows a clear subdivision of Brugmansia Clade into two sublcades - a larger subclade with majority of taxa conforming to the larger morphological group based on corolline and fruit characters and a second subclade including the taxa with narrow tubular corollas and short egg shaped fruits. The two subclades stand well supported (BS 100 and 91). Hence it is proposed that the genus Brugmansia may be subdivided into two sections based on corolline and fruit characters as Section Brugmansia and Section Sanguinea, as explained above.

\section{Conclusions:-}

The present molecular analysis based on ITS 1 and ITS 2 sequences supports the splitting of Datura and Brugmansia and also establishes the distinctiveness of the two genera (BS 100 and 91). D. ceratocaula earlier considered as the connecting link between the two genera, is nested within Datura clade (BS 57) as a distinct species. The three conventional sections of Datura viz. Dutra, Ceratocaulis and Datura (Stramonium) stand well supported in the phylogenetic tree (BS 100, 100 and 83). D. kymatocarpa, D. leichhardtii and D. pruinosa from Section Dutra appear shifted to Section Datura, corroborating earlier observations. D. discolor was nested within the Section Dutra, and the molecular data do not support its intermediary or ancestral ranking, contrary to earlier molecular reports. The divergence of $\mathrm{D}$. discolor from the remaining taxa within the section Dutra is not sufficient enough for the erection of a new section as was proposed earlier. The egg shaped fruit of B. arborea makes it a misfit in Section Brugmansia 
characterized by long spindle shaped fruits. Hence fruit shape alone cannot be depended upon as a distinguishing character for subdividing the genus Brugmansia. The phylogenetic tree observed in the present study shows a clear subdivision of Brugmansia Clade into two well supported sublcades (BS 100 and 91). Hence we propose the subdivision of the genus Brugmansia into two sections based on corolline and fruit characters as Section Brugmansia comprising majority of taxa under the genus characterized by large trumpet or funnel shaped and flared out corollas along with long spindle shaped or short egg shaped fruits and Section Sanguinea with narrow tubular corollas and short egg shaped fruits including B. sanguinea and B. vulcanicola.

Table 1:- Details of the taxa of Brugmansia Pers. and Datura L. collected from Kerala and Tamil Nadu along with author citations

\begin{tabular}{|c|c|c|c|c|c|c|c|c|}
\hline $\begin{array}{l}\mathbf{S} \\
\mathbf{N} \\
\mathbf{0}\end{array}$ & Name of species & $\begin{array}{l}\text { Vernacular } \\
\text { name/ } \\
\text { common } \\
\text { name }\end{array}$ & $\begin{array}{l}\text { Native } \\
\text { range }\end{array}$ & Locality & $\begin{array}{l}\text { Vouch } \\
\text { er No. }\end{array}$ & $\mathbf{N}$ & $\mathbf{E}$ & $\begin{array}{c}\text { Altitu } \\
\text { de }\end{array}$ \\
\hline 1 & $\begin{array}{l}\text { Brugmansiax } \\
\text { candida Pers. }\end{array}$ & $\begin{array}{l}\text { B. candida } \\
\text { 'Tutu' x B. } \\
\text { versicolor } \\
\text { 'Kaskade' }\end{array}$ & $\begin{array}{c}\text { Ecuador } \\
\text {, South } \\
\text { America } \\
\text { - the } \\
\text { hybrid } \\
\text { variety } \\
\text { from } \\
\text { France }\end{array}$ & $\begin{array}{l}\text { Kodaikanal, } \\
\text { Tamil Nadu }\end{array}$ & $\begin{array}{c}\text { S015 } \\
\text { SNCH }\end{array}$ & $\begin{array}{c}10^{\circ} 14^{\prime} 1 \\
6^{\prime \prime}\end{array}$ & $\begin{array}{c}77^{\circ} 29 ’ 2 \\
3^{\prime \prime}\end{array}$ & $\begin{array}{c}2091 \\
\mathrm{~m}\end{array}$ \\
\hline 2 & $\begin{array}{l}\text { Brugmansiax } \\
\text { cubensis } \\
\text { (V.R.Fuentes) } \\
\text { V.R.Fuentes }\end{array}$ & $\begin{array}{l}\text { B. aurea X B. } \\
\text { suaveolens X } \\
\text { B. versicolor }\end{array}$ & $\begin{array}{c}\text { Peru, } \\
\text { Chile } \\
\text { and } \\
\text { Columbi } \\
\text { a, South } \\
\text { America } \\
\text { - the } \\
\text { hybrid } \\
\text { from } \\
\text { Columbi } \\
\text { a }\end{array}$ & $\begin{array}{l}\text { Kodaikanal, } \\
\text { Tamil Nadu }\end{array}$ & $\begin{array}{c}\text { S016 } \\
\text { SNCH }\end{array}$ & $\begin{array}{c}10^{\circ} 14^{\prime} 0 \\
9^{\prime \prime}\end{array}$ & $\begin{array}{c}77^{\circ} 29^{\prime} 3 \\
4^{\prime \prime}\end{array}$ & $\begin{array}{c}1548 \\
\mathrm{~m}\end{array}$ \\
\hline 3 & $\begin{array}{l}\text { Brugmansiasangui } \\
\text { nea (Ruiz \& Pav.) } \\
\text { D. Don }\end{array}$ & - & $\begin{array}{c}\text { Peru, } \\
\text { South } \\
\text { America }\end{array}$ & $\begin{array}{c}\text { Ootacamund, } \\
\text { Tamil Nadu }\end{array}$ & $\begin{array}{c}\text { S013 } \\
\text { SNCH }\end{array}$ & $\begin{array}{c}11^{\circ} 24^{\prime} 2 \\
3^{\prime \prime}\end{array}$ & $\begin{array}{c}76^{\circ} 41^{\prime} 3 \\
5^{\prime \prime}\end{array}$ & $\begin{array}{c}2248 \\
\mathrm{~m}\end{array}$ \\
\hline 4 & $\begin{array}{l}\text { Brugmansia } \\
\text { sanguinea (Ruiz } \\
\text { \&Pav.) D. Don }\end{array}$ & - & $\begin{array}{l}\text { Ecuador } \\
\text {, South } \\
\text { America }\end{array}$ & $\begin{array}{l}\text { Ootacamund, } \\
\text { Tamil Nadu }\end{array}$ & $\begin{array}{c}\text { S014 } \\
\text { SNCH }\end{array}$ & $\begin{array}{c}11^{\circ} 24^{\prime} 1 \\
6^{\prime \prime}\end{array}$ & $\begin{array}{c}76^{\circ} 41^{\prime} 2 \\
9^{\prime \prime}\end{array}$ & $\begin{array}{c}2263 \\
\mathrm{~m}\end{array}$ \\
\hline 5 & $\begin{array}{l}\text { Brugmansiasuaveo } \\
\text { lens (Humb. } \\
\text { \&Bonpl. exWilld.) } \\
\text { Bercht. \& J. Presl. }\end{array}$ & $\begin{array}{l}\text { Angel's } \\
\text { Trumpet }\end{array}$ & $\begin{array}{c}\text { South } \\
\text { east } \\
\text { Brazil, } \\
\text { South } \\
\text { America }\end{array}$ & $\begin{array}{c}\text { Kumili, } \\
\text { Kottayam, Kerala }\end{array}$ & $\begin{array}{c}\text { S012 } \\
\text { SNCH }\end{array}$ & $9^{\circ} 36^{\prime} 4^{\prime \prime}$ & $\begin{array}{c}77^{\circ} 10^{\prime} 1 \\
2^{\prime \prime}\end{array}$ & $\begin{array}{c}1048 \\
\mathrm{~m}\end{array}$ \\
\hline 6 & $\begin{array}{c}\text { Brugmansia } \\
\text { suaveolens (Humb. } \\
\text { \& Bonpl. } \\
\text { exWilld.) Bercht\& } \\
\text { J. Presl. }\end{array}$ & $\begin{array}{l}\text { Angel's } \\
\text { Trumpet }\end{array}$ & $\begin{array}{c}\text { South } \\
\text { east } \\
\text { Brazil, } \\
\text { South } \\
\text { America }\end{array}$ & $\begin{array}{c}\text { Kodaikanal, } \\
\text { Tamilnadu }\end{array}$ & $\begin{array}{c}\text { S018 } \\
\text { SNCH }\end{array}$ & $\begin{array}{c}10^{\circ} 14^{\prime} 1 \\
3^{\prime \prime}\end{array}$ & $\begin{array}{c}77^{\circ} 29^{\prime} 4 \\
1^{\prime \prime}\end{array}$ & $\begin{array}{c}2109 \\
\mathrm{~m}\end{array}$ \\
\hline 7 & Datura inoxia Mill. & $\begin{array}{l}\text { Ummam/ } \\
\text { Downy } \\
\text { Thorn Apple/ } \\
\text { Indian- } \\
\text { Apple/Recur } \\
\text { ved Thorn }\end{array}$ & $\begin{array}{l}\text { Central } \\
\text { and } \\
\text { South } \\
\text { America } \\
\text {, India } \\
\text { and }\end{array}$ & $\begin{array}{c}\text { Coimbatore, } \\
\text { Tamilnadu }\end{array}$ & $\begin{array}{c}\text { S019 } \\
\text { SNCH }\end{array}$ & $\begin{array}{c}11^{\circ} 00^{\prime} 5 \\
4 "\end{array}$ & $\begin{array}{c}76^{\circ} 57^{\prime} 1 \\
4^{\prime \prime}\end{array}$ & $457 \mathrm{~m}$ \\
\hline
\end{tabular}




\begin{tabular}{|c|c|c|c|c|c|c|c|c|}
\hline & & $\begin{array}{c}\text { apple / } \\
\text { Sacred } \\
\text { Thorn Apple }\end{array}$ & China & & & & & \\
\hline 8 & $\begin{array}{l}\text { Datura metel L. } \\
\text { var. fastuosa (L.) } \\
\text { Saff. }\end{array}$ & $\begin{array}{c}\text { Ummam/ } \\
\text { Black Datura }\end{array}$ & $\begin{array}{l}\text { Asia and } \\
\text { Africa / } \\
\text { America }\end{array}$ & $\begin{array}{c}\text { Pallippuram, } \\
\text { Thiruvananthapur } \\
\text { am, Kerala }\end{array}$ & $\begin{array}{c}\mathrm{S} 020 \\
\mathrm{SNCH}\end{array}$ & $\begin{array}{c}8^{\circ} 36^{\prime} 34 \\
, "\end{array}$ & $\begin{array}{c}76^{\circ} 51^{\prime} 2 \\
0 \text { '” }\end{array}$ & $34 \mathrm{~m}$ \\
\hline
\end{tabular}

Table 2 :-Voucher information of Brugmansia and Datura used for molecular study employing ITS markers

\begin{tabular}{|c|c|c|c|c|}
\hline Sl.No & Taxon & $\begin{array}{l}\text { Voucher } \\
\text { No. }\end{array}$ & Locality & GenBank \\
\hline 1 & Brugmansia candida Pers. & $\begin{array}{c}\mathrm{S} 015 \\
\mathrm{SNCH}\end{array}$ & $\begin{array}{l}\text { Kodaikanal, Tamil } \\
\text { Nadu }\end{array}$ & - \\
\hline 2 & B. cubensis (V.R. Fuentes) V.R.Fuentes & $\begin{array}{l}\text { S016 } \\
\text { SNCH }\end{array}$ & $\begin{array}{l}\text { Kodaikanal, Tamil } \\
\text { Nadu }\end{array}$ & - \\
\hline 3 & B. sanguinea (Ruiz \& Pav.) D.Don & $\begin{array}{l}\text { S014 } \\
\text { SNCH }\end{array}$ & $\begin{array}{l}\text { Ootacamund, Tamil } \\
\text { Nadu }\end{array}$ & - \\
\hline 4 & $\begin{array}{l}\text { B. suaveolens (Humb. \& Bonpl. ex } \\
\text { Willd.) Bercht. \& J. Presl }\end{array}$ & $\begin{array}{c}\text { S012 } \\
\text { SNCH }\end{array}$ & Kottayam, Kerala & - \\
\hline 5 & $\begin{array}{l}\text { B. suaveolens (Humb. \& Bonpl. ex } \\
\text { Willd.) Bercht. \& J. Presl }\end{array}$ & $\begin{array}{c}\text { S018 } \\
\text { SNCH }\end{array}$ & $\begin{array}{l}\text { Kodaikanal, Tamil } \\
\text { Nadu }\end{array}$ & - \\
\hline 6 & Bragmansia candida Pers. & & Mexico & JX467598, JX467600 \\
\hline 7 & B.sanguinea (Ruiz \& Pav.) D.Don & & Mexico & JX467601 \\
\hline 8 & $\begin{array}{l}\text { B.suaveolens (Humb. \& Bonpl. ex } \\
\text { Willd.) Bercht. \& J.Presl }\end{array}$ & & Mexico & $\begin{array}{c}\text { JX467597, HG738853, } \\
\text { LC076493 }\end{array}$ \\
\hline 9 & B. vulcanicola (A.S.Barclay) R.E.Schult. & & USA & KP100296 \\
\hline 10 & Datura ceratocaula Ortega & $\begin{array}{c}\mathrm{S} 07 \\
\mathrm{SNCH} \\
\end{array}$ & USA & - \\
\hline 11 & D. inoxia Mill. & $\begin{array}{c}\text { S019 } \\
\text { SNCH }\end{array}$ & $\begin{array}{c}\text { Coimbatore, Tamil } \\
\text { Nadu }\end{array}$ & - \\
\hline 12 & D. metel L. var. fastuosa (L.)Saff. & $\begin{array}{c}\mathrm{S} 020 \\
\mathrm{SNCH}\end{array}$ & $\begin{array}{c}\text { Thiruvananthapuram, } \\
\text { Kerala }\end{array}$ & - \\
\hline 13 & D. stramonium L. & $\begin{array}{c}\text { S017 } \\
\text { SNCH }\end{array}$ & $\begin{array}{c}\text { Ootacamund, Tamil } \\
\text { Nadu }\end{array}$ & - \\
\hline 14 & D. ceratocaula (Ortega) Court ex Gaede & - & Mexico & JX467608 \\
\hline 15 & D. biscolor Pers. & - & Germany & HQ658577, JX467605 \\
\hline 16 & D. ferox L. & - & France & HQ658579, HQ658580 \\
\hline 17 & D. inoxia Mill. & - & China, UK & $\begin{array}{c}\text { JX467607, HQ658591, } \\
\text { HQ658588 } \\
\end{array}$ \\
\hline 18 & D. lanosa Barclay ex Bye & - & Mexico & JX467603 \\
\hline 19 & D. leichhardtii Benth. & - & China & HQ658593 \\
\hline 20 & D. metel L. & - & China, Indonesia & $\begin{array}{l}\text { JX467604, HQ658595, } \\
\text { LC076492, HQ658578 }\end{array}$ \\
\hline 21 & D. pruinosa Greenm & - & Mexico & JX467610 \\
\hline 22 & D. quercifolia Kunth & - & France & HQ658598, JX467612 \\
\hline 23 & D. reburra Barclay & - & Mexico & JX467606 \\
\hline 24 & D. stramonium L. & - & France, Mexico & $\begin{array}{l}\text { KF022335, JX467611, } \\
\text { DQ006041, HQ658606 }\end{array}$ \\
\hline 25 & D. kymatocarpa Barclay & - & Mexico & JX467609 \\
\hline 26 & D. wrightii Regel & - & Mexico & JX467602 \\
\hline
\end{tabular}




\begin{tabular}{|c|c|c|c|c|}
\hline & & & & \\
\hline 27 & Nicotiana linearis Phil. & - & UK & AJ492425 \\
\hline 28 & N. obtusifolia M. Martens \& Galeotti & - & USA & DQ272593,DQ272597 \\
\hline 29 & N. tabacum L. & - & USA & AJ012364 \\
\hline
\end{tabular}

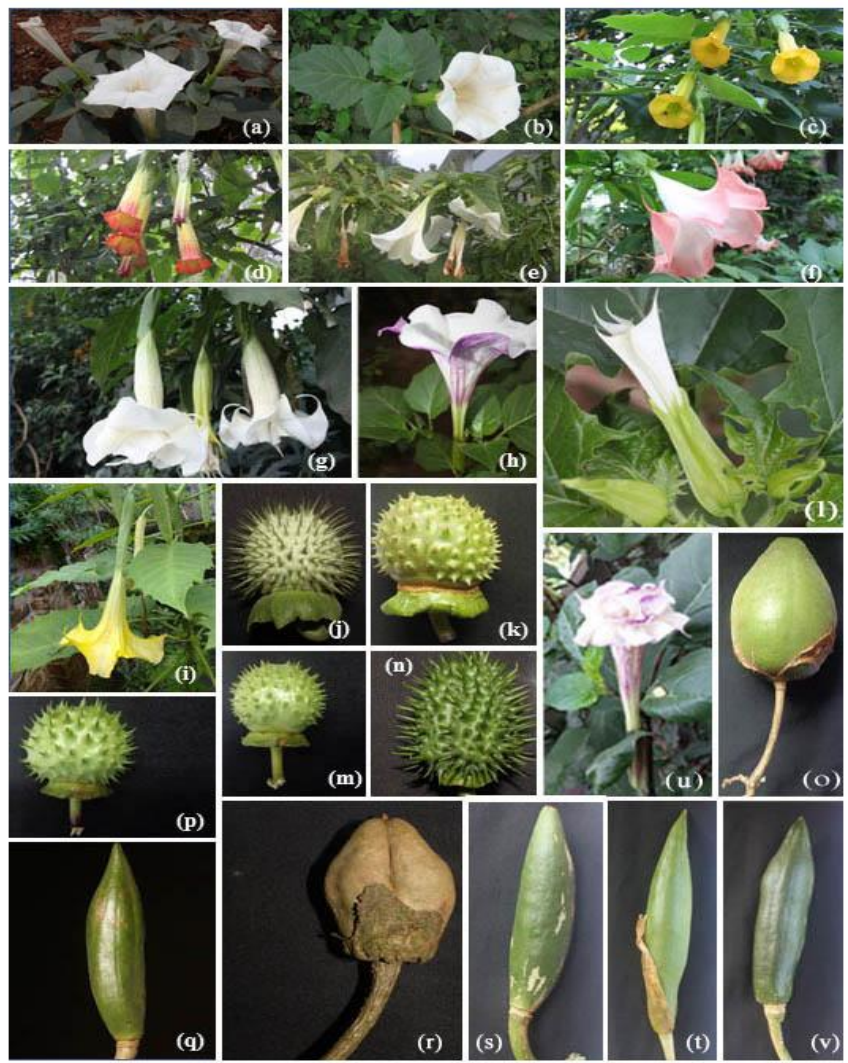

Figure 1. The diversity of flowers and fruits in Datura and Brugmansia - a \& j - Datura inoxis Mill - Flower \& Fruit; b \& m - Datura metel L var metel Fl \& Fr c c \& r Brugmansia sanguinea 'Oroverde'- Fl \& $\mathrm{Fr}$. d \& $\mathrm{O}-$ Brugmansia sanguinea 'MishaTora'- Fl \& Fr.; e \& s - Brugmansia suaveolens 'Valley White'-Fl. \& Fr.; f \& q Brugmansia suaveolens 'Remembrance'- Fl. \& Fr.; k \& u - Datura metel L var, fastuosa (L.) Saff - Fl. \& Fr, h \& p - Datura metel L. var. rubra-Fl. \& Fr.; i \& t - Brugmansia x cubensis 'Dr.Seuss'- Fl. \& Fr.; 1 \& n - Datura stramonium L- Fl. \& Fr.; g \& v Brugmansia $x$ candida Pers. 'Charleston'-Fl. \& Fr 


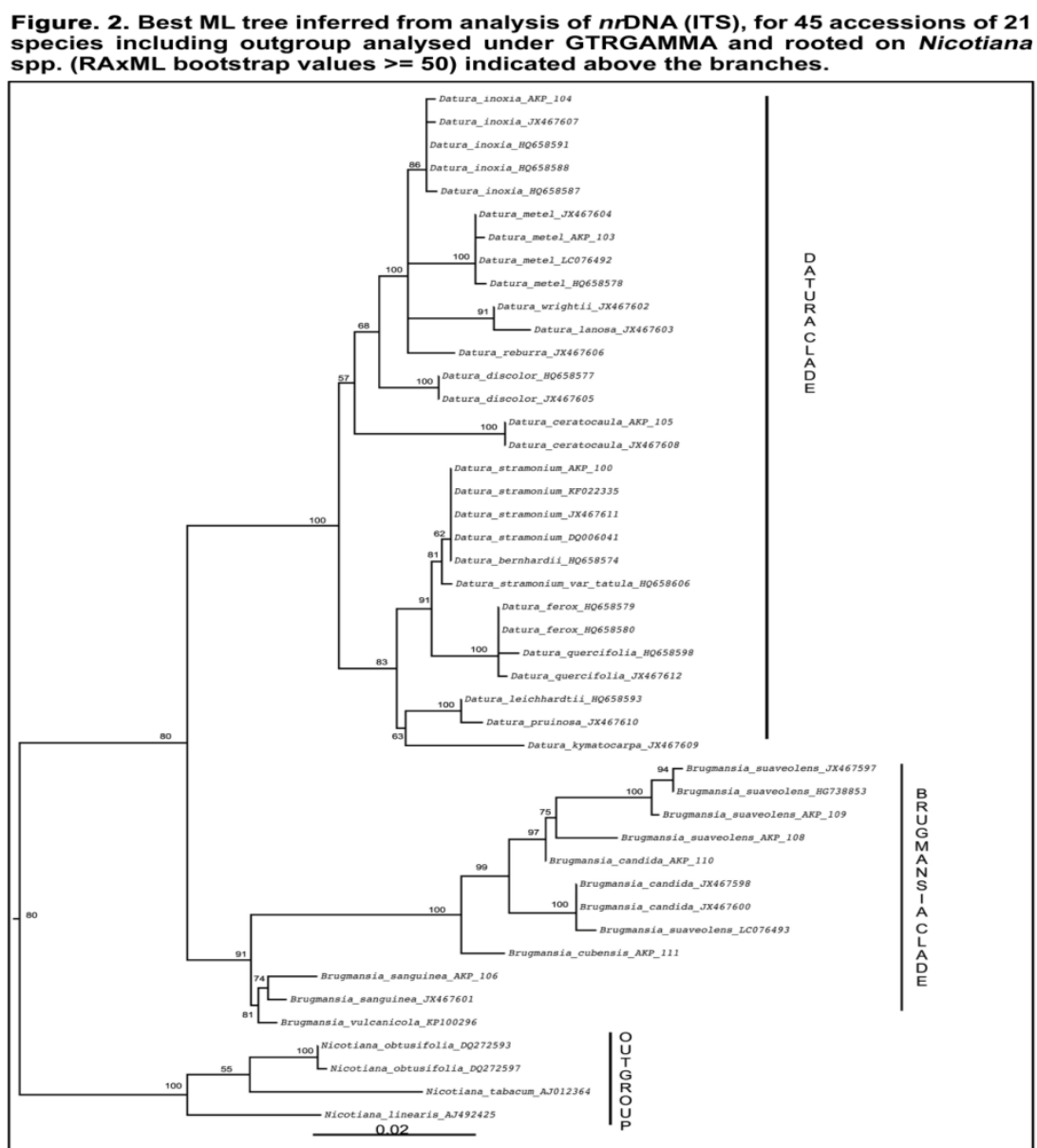

\section{Acknowledgements:-}

The authors are thankful to the University of Kerala for financial support and the Principals, Sree Narayana Colleges, Kollam and Chempazhanthy for facilities provided.

\section{References:-}

1. Dunal, M.F. 1852. Solanaceae. In: Prodromus Systematis Naturalis Regni Vegetabilis 13(1). De Candolle ALPP

2. (ed.).Victor Masson: Paris, pp. 1-690.

3. APG III. 2009. An update of the Angiosperm Phylogeny Group classification for the orders and families of

4. flowering plants: PG II. Bot. J. Linn. Soc.141: 399-436.

5. Avery, A.G., Satina, S. and J. Rietsema. 1959. Blakeslee-The Genus Datura. Ronald Press Company, New York,

6. $289 \mathrm{pp}$.

7. Baldwin, B.G. 1992. Phylogenetic utility of the internal transcribed spacers of nuclear ribosomal DNA in plants: an

8. example from the Compositae. Mol. Phylogenet. Evol. 1: 3-16.

9. Barclay, A.S. 1959. New considerations in an old genus : Datura. Botanical Museum leaflets (Harvard University)

10. 18: $245-272$

11. Bemhardi J.J. 1833. Uber die Arten der Gattung Datura. Trommsdorf Neues J Pharmacie 26:118-158.

12. Bristol, L.M. 1966. Notes on the species of tree daturas. Bot Mus Leafl (Harvard University) 21:229-248.

13. Bristol, L.M. I969. Tree Datura drugs of the Colombian Sibundoy. Botanical Museum Leaflets, Harvard University 22:165-227. 
14. Bye, R. and V. Sosa. 2013. Molecular phylogeny of the Jimson weed genus Datura (Solanaceae). Syst. Bot. 38(3) :

15. $818-829$.

16. Chase, M.W., Soltis, D.E. and R.G. Olmstead. 1993. Phylogenetics of seed plants: an analysis of nucleotide

17. sequences from the plastid gene rbcL. Ann. Miss. Bot. Gard. 80 : 528-580.

18. D'Arcy, W.G. 1979. The classification of the Solanaceae. In: The Biology and Taxonomy of the Solanaceae. J.G.

19. Hawkes, R.N. Lester and A.D. Skelding. (eds.). Academic Press, London. pp. 3-48.

20. D’Arcy, W.G. 1991. The Solanaceae since 1976, with a review of its biogeography. In: Solanaceae III: Taxonomy,

21. Chemistry, Evolution. J.G. Hawkes, R.N. Lester, M. Nee and N. Estrada. (eds.). Kew: Royal Botanic Gardens and

22. Linnean Society of London. pp. 75-137.

23. Dabur, R., Ali M., Singh H., Gupta J. and G. Sharma. 2004. A novel antifungal pyrrole derivative from Datura metel

24. leaves. Pharmazie, 59 : 568-570.

25. Dhanya, C. and V. Devipriya. 2016. Pollen morphological studies on two Solanaceous genera: Brugmansia Pers.

26. and Datura L. Int. J. Adv. Res. 4(9) : 1879-1887.

27. Fosberg, F.R. 1959. Nomenclatural notes on Datura L. Taxon, 8 : 52-57.

28. Gaut, B.S., Tredway, L.P., Kubik, C., Gaut, R.L. and W. Meyer. 2000. Phylogenetic relationships and genetic

29. diversity among members of the Fesuca-Lolium complex (Poaceae) based on ITS sequence data. Plant Syst. Evol.

30. 224: 33-53.

31. Geeta, R. and W. Gharaibeh. 2007. Historical evidence for a pre-Columbian presence of Datura in the Old World

32. and implications for a first millennium transfer from the New World. J. Biosci. 32 : 1227-1244.

33. Griffin, W. and G.D. Lin. 2000. Chemotaxonomy and geographical distribution of tropane alkaloids.

34. Phytochemistry, 53: 623-637.

35. Haegi, L. 1976. Taxonomic account of Datura L. (Solanaceae) in Australia with a note on Brugmansia Pers.

36. Australian J. Bot. 24: 451-435.

37. Hammer, K.A., Romeike and C. Tittel. 1983. Vorarbeiten zur monographischen Darstellung von Wildpfl

38. anzensortimenten: Datura L., sections Dutra Bemh., Ceratocaulis Bemh. Datura; Kulturpflanze, 31 : 13-75.

39. Hay, A., Gottschalk, M. and A. Holguin. 2012. Huanduj : Brugmansia. Royal Botanic Gardens, Kew. pp : 88169.

40. Hunziker, A.T. 1979. South American Solanaceae: a synoptic survey.Pp.49-86 In: In: The Biology and Taxonomy of

41. the Solanaceae. J.G. Hawkes, R.N. Lester and A.D. Skelding. (eds.). Academic Press, London.

42. Hunziker, A.T. 2001. Genera Solanacearum: The Genera Solanaceae. Illustrated, arranged According to a New

43. System. Gantner, Ruggell, Liechtenstein.

44. Jiao, M., Luna-Cavazos, M. and R. Bye. 2002. Allozyme variation in Mexican species and classification of Datura

45. (Solanaceae); Plant Syst. Evol. 232: 155-166.

46. Knapp, S. 2002. Floral diversity and evolution in the Solanaceae. In: Developmental Genetics and Evolution. Q.C.B.

47. Cronk, R.M. Bateman and J.A. Hawkins. (eds.). Taylor and Francis, London, UK. pp. 267-297.

48. Kron, K.A. and J.M. King. 1996. Cladistics relationships of Kalmia, Leiophyllum and Loiseleuria (Phyllodoceae,

49. Ericaceae) based on rbcL and nrITS data. Syst. Bot. 21:17-31.

50. Lagerheim, G. 1895. Monographie der ecuadoriarischen Arten der Gattung Brugmansia Pers. Engler's Bot. Jahrb. 20: 655-668.

51. Lockwood, T.E. 1973. Generic recognition of Brugmansia. Botanical Museum Leaflets, Harvard University. 23: 273-284.

52. Luna-Cavazos, M. and R. Bye. 2000. Phenetic analysis of Datura section Dutra (Solanaceae) in Mexico. Bot. J.

53. Linn. Soc. 133: 493-507. 
54. Mace, E.S., Gebhardt, C.G. and R.N. Lester. 1999. AFLP analysis of genetic relationships in the tribe Datureae (Solanaceae); Theor. Appl. Genet. 99: 634-641.

55. Mace, E.S., Vosman, B., Lester, R.N. and G.M. van der Weerden. 2000. Systematic relationships in the tribe

56. Datureae (Solanaceae): evidence from ribosomal DNA sequences of the internal transcribed spacer 1 region and isozymes. Pl. Syst. Evol. (c.f. Mace et al. 1999).

57. Mino, Y. 1994. Identical amino-acid sequence of ferredoxin from Datura metel and D.inoxia. Phytochemistry, 35: 385-387.

58. Mino, Y. 1995. Protein chemotaxonomy of genus Datura. IV. Amino acid sequence of Datura ferredoxins depends not on the species but the section of Datura plants from which it comes. Chem. Pharm. Bull. (Tokyo). 43(7): 1186-1189.

59. Nandini, D., Ravikumar, B.S. and K.K. Prasanna Rashmi. 2015. Morphometric analysis of Datura plant to

60. understand variation and similarities among four major species. Med. Aromat. Plants, 4: 209.

61. Nee, M.1991. Datura and Brugmansia: Two genera or one? Solanaceae Newsletters, 3: 27-35.

62. Olmstead, R.G. and J.D. Palmer. 1992. A chloroplast DNA phylogeny of the Solanaceae : subfamilial relationships and character evolution. Ann. Miss. Bot. Gard. 79: 346-360.

63. Olmstead, R.G., Bohs, L., Migid, H.A., Santiago-Valentin, E., Garcia, V.F. and S.M. Collier. 2008. A molecular phylogeny of the Solanaceae. Taxon, 57:1159-1181.

64. Persoon, C.H. 1805. Synopsis Plantarum, 1: 216-217.

65. Persson V., Knapp, S. and S. Blackmore. 1999. Pollen morphology and the phylogenetic analysis of Datura and

66. Brugmansia. In: M. Nee, D.E. Symon, R.N.Lester \& J.P. Jessop (eds.). Solanaceae IV : Advances in Biology and

67. Utilization. Royal Botanic Gardens, Kew. pp : 171-187.

68. Qiu, Y.L., Chase, M.W., Hoot, S.B., Conti, E., Crane, P.R., Sytsma, K.J. and C.R. Parks. 1998. Phylogenetics of the Hamamelidae and their allies: parsimony analyses of nucleotide sequences of the plastid gene rbcL. Int. J. Plant Sci. 159: 891-905.

69. Randhava, G.S. and A. Mukhopadhyay. 1986. Floriculture in India. Allied Pub. Pvt. Ltd., New Delhi, pp : 142143.

70. Safford, W.E .1921. Synopsis of the genus Datura. J. Wash. Acad. Sci. 11: 173-189

71. Sasidharan, N. 2004.Biodiversity Documentation for Kerala. Part 6. Flowering Plants. KFRI Handbook No.17. I

72. pp.276-278.

73. Schultes, R.E. 1979. Solanaceous hallucinogens and their role in the development of New World cultures. Pp. 137160 In: Hawkes J.G., Lester R.N. and A.D.Skelding (eds.), The Biology and Taxonomy of the Solanaceae. Academic Press, London.

74. Shaw, J.M.H. 2000. Brugmansia, Datura. In: The European Garden Flora - Loganiaceae to Compositae. Vol. VI.

75. J. Cullen and S.M. Walters. (eds.). Cambridge University Press, Cambridge, UK. pp. 232-267.

76. Siklos, B. 1993. Datura rituals in the Vajramahabhairava-Tantra. Curare, 16 : 1-

77. Stamatakis, A. 2006. RAXML-vi-hpc : maximum likelihood-based phylogenetic analysis with thousands of taxa and mixed models. Bioinformatics, $22: 2688-2690$.

78. Stamatakis, A., Hoover, P. and J. Rougemont. 2008. A rapid bootstrap algorithm for the RAXML Web servers. Syst. Biol, 57 : 758-771.

79. Symon, D.E. and L.A.R. Haegi. 1991. Datura (Solanaceae) is a new world genus. In: Solanaceae III: Taxonomy-

80. Chemistry-Evolution. J.G. Hawks, R.N. Lester, M. Nee and N. Estrada. (eds.). Royal Botanic Gardens, Kew:

81. Richmond, Surrey. pp.197-210.

82. The Plant List, 2013, Version 1.1. Published on the Internet; http://www.theplantlist.org/ (accessed I st January).

83. Thompson, J.D., Higgins, D.G. and T.J. Gibson. 1994. CLUSTAL W: improving the sensitivity of progressive

84. multiple sequence alignment through sequence weighting, position-specific gap penalties and weight matrix choice. Nucl. Acids Res. 22: 4673-4680.

85. Thompson, J.D., Gibson, T.J., Jeanmougin, F. and D.G. Higgins.1997. The CLUSTAL-X windows interface:

86. flexible strategies for multiple sequence alignment aided by quality analysis tools. Nucl. Acids Res. 25: 48764882.

87. White, T.J., Burns, T., Lee, S and J. Taylor. 1990. Amplification and direct sequencing of fungal ribosomal RNA genes for phylogenetics. In: M.A. Innis, D.H. Gelfand, J.J. Snisky and T.J. White. (eds.). PCR Protocols, a guide to Methods and Applications. Academic Press. San Diego C.A. Chapt. 38. pp. 315-322. 